\title{
발표논문
}

\section{조선후기 송광사 가람중창의 경제적 배경}

정용범 | 부산대학교 · 동서대학교 강사

\section{국문초록}

오늘날 전통사찰들이 일정한 정도의 규모를 유지할 수 있었던 것은 조선시 대 불교탄압의 현실을 슬기롭게 극복한 사원의 자구적 노력에 의한 것이었 다. 본고는 사원의 자구적 노력을 통한 가람의 규모를 유지할 수 있었던 구 체적 실례를 조선후기 松廣寺의 중창을 통해 살펴보았다.

조선시대 송광사는 약 3,000간에 달하는 건물과 3 400명에 달하는 승려 들이 거처하는 대찰로서 이러한 규모를 유지하기 위해서는 상당한 정도의 경제운영이 필요했다. 송광사는 헌종 8년(1842) 대화재로 거의 폐사 상태 
까지 내몰렸다가 제5중창을 통해 다시 이전의 모습에 비견될 만큼 규모를 회복하였다. 제 5 중창은 국가가 적극 지원하였는데, 그것은 송광사가 왕실 의 願堂이자 封山(조선후기 국가의 산림관리정책에 따라 지정된 특정 산 림)으로 국가의 보호를 받는 사찰로 지정되었기 때문이다.

송광사는 지방관아에 다양한 종류의 승역을 납부해야 했는데, 조선후기 봉산과 원당으로 지정됨으로써 국가로부터 상당한 정도의 조세와 僧役의 감면을 받았다. 원래 송광사가 부담한 승역은 현금징수, 현물징수, 노동력 징수가 있었다. 송광사의 승역부담을 통해 송광사의 사원경제가 종합적이 면서도 매우 컸음을 알 수 있다.

\section{1. 머리말}

조선시대 억불정책 아래 승려들은 신분적 천시를 받으면서 제반 잡역 에 동원되어 온갖 수탈을 감당하여야 했다. 승려들은 관청을 비롯한 각 종 건축물의 營建에 木工이나 石工 그리고 畫工으로 징발되기도 하였 으며 ${ }^{1)}$, 지방의 관청과 향촌세력에 예속되어 각종 잡역을 무상으로 제 공하기도 하였다. 이에 따라 승려들은 극심한 군역과 잡역을 감당하지 못하고, 도망하는 수가 점차 증가하여 큰 사찰조차도 폐허가 되다시피

1) 윤용출, 「 17 세기 이후 僧役의 강화와 그 변동」『조선후기의 요역제와 고용노동』, 서울대학교 출판부, 1998 . 
하였다2). 이에 대해 각 사원들은 자구책으로 가람을 유지하기 위한 자 산을 생산하기 시작하였다 ${ }^{3}$. 대사찰의 경우 왕실의 원당 또는 기도도 량으로 지정되어 왕실의 하사금이 직접 주어지거나 공명첩을 발행하 여 재원을 마련하기도 하였고, 세력 있는 가문의 원찰이 되어 재정적 지원을 받기도 하였다 ${ }^{3}$. 국가의 불교계에 대한 다방면의 탄압 속에서 도 사원이 일정한 정도의 가람 규모를 유지할 수 있었던 것은 이러한 사원의 자구적 노력에 의한 것이며, 그 규모는 어느 정도의 변동은 있 지만 오늘날까지 면면히 이어져왔다5).

본고는 사원의 자구적 노력을 통한 가람의 규모를 유지할 수 있었던 구체적 실례를 삼보사찰의 하나인 松廣寺를 통해 찾아보고자 한다. 특 히 본고에서는 송광사의 5 차 중창을 중심으로 사원의 사세가 어떻게 유지되었는가를 살펴보고자 한다. 송광사의 5 차 중창은 국가로부터 전 폭적인 지원을 받아 이루어졌는데, 그 배경에는 송광사가 육상궁 원당 과 율목봉산 지정으로 왕실과 국가로부터 중요한 사원으로 인식되었 기 때문이다. 한편 원당과 봉산지정을 통해 송광사는 국가로부터 각종 僧役을 면제받고 있었는데, 이를 통해 조선후기 송광사가 지역사회에

2) 오경후,「朝鮮後期 佛敉界의 變化相」『慶州史學』22,251胥.

3) 사찰의 가람 유지를 위한 자구적 노력에 대해서는 김갑주, 『朝鮮時代寺院經濟研究』, 동화출판 공사, 1983. 및 한상길, 「조선후기 사원의 불사와 寺刹契」『佛敉學報』 28 참조.

4) 한상길, 「개화기사찰의 조직과 운영」『불교근대화의 전개와 성격』, 조계종 불학연구소, 2006, 26 29쪽.

5) 박병선, 「朝鮮後期願堂研究」, 영남대박사학위논문, 2002,75쪽의 주 243)에는 조선시대 사찰의 수적 추이를 정리하였다. 그에 따르면 신증동국여지승람(1531)에는 1,658 개의 사찰이 여지도서 (1760)에서는 1,537 개, 가람고(1776)에서는 1,449 개, 조선총독부통계연보(1915)에는 1,401 개, 조선 불교통사(1918)에는 1,478 개의 사찰이 존재한 것으로 되어있다. 조선시대를 거치면서 새로운 사 찰의 창건 등도 있었겠지만 이를 무시하고 단순히 계산하면 약 250 300여 개의 사찰이 폐사되었 다고 보인다. 그 나머지 사찰들은 규모의 축소는 있었겠지만 일정한 정도 사세를 유지하였을 것 으로 생각된다. 
서차지하는 경제적 위상도 살펴보고자 한다. 여기에 대한 기본 자료로 는 1932년에 간행된 『曹溪山松廣寺史庫』를 이용하였다.

\section{2. 조선후기 송광사의 가람규모와 제 5 중창}

\section{1) 조선후기 송광사의 가람규모}

조선시대 송광사가 어느 정도의 규모를 이루고 있었는지에 대해서는 정확하게 알 수는 없어나, 송광사와 관련한 몇 편의 시가 남겨져 있어 그 규모를 짐작할 수 있다. 먼저 조선중기의 문신 沈光世(1577 1624)는 송광사에는 단청한 높은 불전들이 울창하다고 하였으며》, 숙종대의 문 신인 金昌拿(1653 1722)은 중첩된 건물들 속에는 선승들이 가득하다8) 고 하였다. 1882년 5월 승평군 일대를 유람하였던 宋秉蔹(1836 1905) 은 송광사에 대해 화려하고 웅장한 건물들이 골짜기에 빽빽이》 들어서 있다고 하였고, 金允植(1835 1922)은 “方丈이 3,000간10”’이었다고 표현 하였다. '방장 3,000 간'은 김윤식이 방문하였을 당시의 송광사의 규모 가 아니라 조선시대 송광사의 건물이 그 정도의 규모였다는 이야기를

6) 이하『串庫』로 줄여표현한다. 『사고』는 모두 4부로 이루어져 있는데, 인물부, 건물부, 잡부, 산림부로 구성되어 있다.

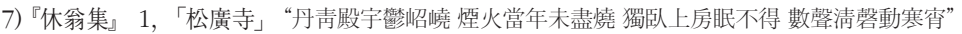

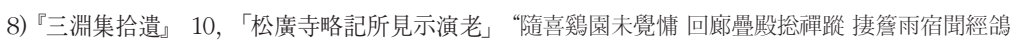
護塔雲嘘眝釚龍 $\ldots .$.

9) 『淵齊先生文集』21, 「遊昇平記」“暮入松廣寺宿東寮甲辰 登眞樂臺俯見寺刹 宏麗重疊 彌滿一 洞 $\cdots$ 得仙嚴寺其排布不及松廣 而幽遑之趣亦一勝境也”

10）雲養集』1, 「昇平舘集」松廣寺 “海東三寶刹松廣獨擅奇 $\cdots$ 風流雖云邀 典型良在茲山僧慣迎 客简與勤相隨 方丈三千間 $\ldots .$. 
듣고서 시적으로 표현한 것이 아닌가 한다. 왜냐하면 1923년부터 시작 된 송광사의 6차 중창11)이 끝나고 난 뒤 1927년 7월 당시 송광사는 70 여동의 건물이 있었다고 기록하고 있어 ${ }^{12)}, 70$ 여 동의 전각으로 3,000 간 을 이루기는 무리해 보인다. 따라서 1927년 당시의 송광사의 전각은 후 술할 1842 년의 대화재 이후 축소된 형태로 복구된 것으로 볼 수 있다.

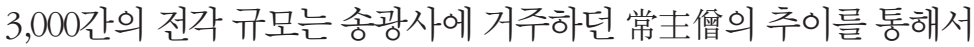
도 짐작할 수 있다. 송광사는 광해군 원년(1609) 200여 명, 숙종 4년 (1678)경 500여 명, 영조 26년(1750)경 400여 명, 정조 20년(1796)경에서 순조 26년(1826)경까지 400여 명, 철종 6년(1855)경 300여 명, 고종 31 년(1894)경에서 隆熙 원년(1907)까지 약 200여 명13), 1931년 150여 명14) 으로 나와 있어 조선후기 송광사는 수많은 선승들이 거주하는 대찰이 었다. 특히 일시적이기는 하지만 광해군 연간에 600 여 명, 영조 연간에 는 1,000 여 명이 기거하던 대찰로서, 이들이 머물 수 있는 가람의 규모 를 유지하였음을 짐작할 수 있다. 이처럼 송광사에 많은 전각과 다수의 승려들이 거주할 수 있기 위해서는 그에 걸맞는 경제규모를 유지하여 야 했다. 조선전기에 송광사는 130 結의 전지를 소유하고 있었다. ${ }^{15)}$ 임

11) 송광사의 6차 중창은 1923 년부터 시작되어 대략 1926년 경 마무리된 것으로 보인다. 6 차 중창에 는 寺監庫·東川 대변소 · 碑殿의 담장과 문 · 海淸堂의 별실 등이 새로 조영되었고, 明星閣을 비 롯하여 몇 채의 건물의 문이나 목욕실과 같은 부속시설이 중건되었다. 중수된 건물로는 龍華堂, 鐘鼓閣 외에 15 채의 건물들 전체 또는 일부가 보수되었다. 또 설법전을 비롯하여 13 채의 건물은 기와를 새로이 갈았다.(『串庫山林部』「3장 벌채」 제 3 절 제6차 중창 때의 벌채 참조.)

12)『史庫 山林部』「附錄 施業案」제 1 차 송광사 寺有林 施業案 說明書에는 “건물 70 여 동이 있는 데 무엇보다도 희귀한 활엽수의 큰 목재를 사용하여 세운 것을 보아도 ...”라고 되어있다. 현재의 송광사는 대략 80 여 동의 전각들로 이루어져 있다. (김정문 · 정룡 · 김재식, 「曹溪山 松廣寺의 空間構成原理에 關한 研究」『韓國傳統造景學會誌』23-1, 2005 참조.)

13)『史庫 건물부』「松廣寺沿革」(法衆之增減)

14)『史庫 산림부』「同苦錄」

15) 『세종실록지리지』 순천도호부조. 
란이후 약 20여년 향교와 官屯의 침탈을 받았지만 應禪 화상의 노력으 로 옛 땅을 거의 회복하였으며, 이후 檀越의 願入沓, 祭位沓, 燈燭沓, 影 幀沓, 佛糧沓, 各初沓 등을 통해 송광사는 사세를 유지해 갈 수 있었다. 이외 각종 寶들도 송광사의 가람운영을 위해 필요한 경제기반이 되었 다. ${ }^{10}$ 이러한 경제적 기반 외에 송광사는 紙所를 비롯한 다수의 수공업 시설을 통해 사찰에서 필요한 다양한 물자들을 생산하여 자체 소비하 기도 하고, 지역 관청이나사회에 공급하기도 하였다.

\section{2) 송광사 제 5 중창}

임진왜란 이후 폐허가 된 송광사를 복구하기 위해 전력을 기울이던 이 는 송광사의 30대 주지를 역임한 應禪 화상이었다. 그는 정유재란으로 폐허가 된 송광사를 복구하기 위하여 자신의 재산을 모두 기울이고, 화 주를 세워 선조34년(1601)부터 수각, 임경당, 보조암 등을 시작으로 송 광사의 건물들을 차례로 중건하였다. 이것이 송광사의 제 4 중창이다. 그럼에도 자체의 노력만으로는 송광사를 임진왜란 이전과 같은 규모 로 회복하기 어려웠던 응선 화상은 당시 지리산에 머물고 있던 浮休 禪 師에게 도움을 청하게 되고, 부휴 선사와 그 문도들의 적극적인 협조 아래 송광사는 이전의 가람의 규모를 거의 회복하기에 이르렀다. 송광 사의 제 4 중창의 불사가 거의 마무리된 것은 광해군 4 년(1612)이었다. ${ }^{17}$ 제 4 중창을 통한 송광사의 가람규모가 대략 3,000간이 아니었을까 한 다. 제 4 중창을 거쳐 대가람을 유지하던 송광사는 헌종 8 년(1842) 3월의

16)『史庫 건물부』「松廣寺沿革」

17) 『史庫 건물부』「松廣寺沿革」 
대화재로 송광사의 절반이 넘는 많은 건물이 소실되었다. ${ }^{18)}$ 헌종 8 년 3월 2일 子時에 落霞堂에서 발화된 화염은 때마침 회오리바람을 타고 순식간에 사찰 서반부를 삼켜버렸다. 대웅전을 비롯하여 佛宇 5所, 僧 寮 8屋, 公舍 12 처로 합계 2,152 간에 달하는 건물이 소실되었으며, 行解 로에서 龍華堂과 法性寮로 이르는 동반부와 후방 高臺 위에 있던 禪院 일대는 피해를 입지 않았다.

송광사에서는 피해내용을 순천부에 보고하였고, 이에 순천부 色 吏가 實跡을 조사하여 이를 전주감영에 보고하였다. 보고를 받은 전 주감영에서는 향후 10 년간 官用進上과 各廳에 쓰일 大小物種을 탕감 해주었다. 한편 4월 8일 송광사에서는 奇峰, 龍雲 두 선사가 직접 상경 하여 영의정 趙寅永을 접견하여 대화재의 전말을 보고하고 복구 작업 을 청원하였다. 본격적인 송광사의 복구를 위한 준비작업은 9월에 들 어와서 진행되었다. 9월 7일 조정에서 중창공사의 지원에 대한 명령이 전주감영으로 하달되자감영에서는 9월 10일 공사비 조달을 위하여 비 변사와 예조에 空名帖 1,000 장과 春曹八道勸善文 발급을 청원하였다. 해를 넘겨 헌종 9년 2월 12일에 비변사로부터 공명첩 500장과 僧帖 200 장, 예조로부터 춘조팔도권선문이 발급되어 감영에 도착하고, 이에 3 월 19일 공명첩의 가격이 책정되어 전라도 안에서 發賣하고 팔도권선 문은 전국 각지로 돌려 선임된 化士들로 하여금 權善施主錢을 化入하 게 되었다.

송광사에서는 1842 년 10 월 水使와 순천부에 벌채허가를 얻어 벌목 작업을 시작하여 1843 년 仲春에 건축공사에 들어가 대웅전, 명부전, 凝

18) 송광사의 제 5 중창과 관련된 가람의 규모나 공사의 진행과정 등에 대해서는 徐致祥·金純一, 「松廣寺 第五重創工事에 관한 研究」『大韓建築學會論文集』6-1(통권27), 1990 참조. 
香閣, 법왕문, 종각, 서방장, 觀音爐殿을 중건하고, 1844년에는 道成堂, 普濟堂, 문수전을, 1845년에는 佛糧庫, 上庫, 各庫를, 1846년에는 관음 전을, 철종 7년(1856)에는 大藏殿, 해탈문, 三日庵을 중건하여 13년에 걸친 대역사 끝에 대웅전을 비롯한 소실 건물의 일부나마 16 종의 건물 이 완공되었다. 공사를 추진하는 데에는 사찰의 자구노력도 지대하였 지만, 공사재원의 마련과 運材赴役 등 국가의 재정지원이 절대적 힘이 되었는데, 국가지원의 명분은 송광사가 艈祥宮 願堂이자 栗木封山으 로 지정되었기 때문이다.

국가의 지원에도 불구하고 13 년이라는 장기간의 공사는 그만큼 재 정적 여건이나 공역 동원에 어려움이 적지 않았음을 말해준다. 중건규 모도 소실 전의 間數와 비교하여 축소되어 소실된 건물의 일부만이 복 구되었다. 대웅전, 법왕문, 관음전, 대장전, 도성당 등은 규모가 축소

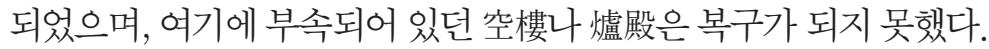

공사비는 대부분 관부로부터 발급된 공명첩의 發賣錢과 팔도권선 문에 의한 시주전의 化入으로 조달되었으며 ${ }^{19)}$, 이외 사찰 자체로 마련 된 勸帒施主錢이나 田沓放賣錢, 개인시주전 등도 있었다. 중창공사에 지원된 공명첩은 俗人공명첩 500장과 僧人공명첩 200장으로 모두 700 장으로 전주를 비롯하여 전라도의 각 읍에 발매되어서 11,642 량이 확 보되었는데, 그 중에서 10,419량 3전 6푼이 송광사로 전달되었다. 한편 권선시주전은 공사 전반의 책임자인 龍雲師를 都化主로 하고 이하 18 인의 化士를 선임하여 전국 각지의 시주자들로부터 勸善册에 금액을 기입하여 거두었는데, 권선시주전 4,990량 8전 중 용운선사가 2,592량

19) 徐致祥·金純一, 위의 논문, 1990 의 83쪽 표3의 化財一覽表에 의하면 공사비 총액 21,641량 3전 3푼 중에서 空名帖價가 10,419량 3전 6푼, 권선시주전이 4,998량 8전으로 전체의 3/4을 차지 하였다. 
4전 9푼을 거두어서 전체의 약 절반에 해당하며, 『大乘禪宗曹溪山松 廣寺誌』의 化財一覽表에는 공명첩가와 運材赴役防錢, 勸帒錢도 모 두 용운선사의 化入金으로 되어 있어서 용운선사가 공사비 모금의 총 책임자이자 중창주로서 활동했음을 알 수 있다. ${ }^{20)}$

제5중창을 통해 송광사는 상당한 정도 복구되었다. 이후에도 송광사 는 회복되지 못한 건물이나 새로운 전각을 세우기 위해 계속해서 노력 했다. 이는 제 5 중창 공사가 끝난 지 7년 후인 철종 14 년(1863)에 용운선 사가 로우의 수리를 전담하는 修理廳을 설치하여 계속되는 건축공사 를 전담할 상설기구를 설치하였음을 통해서 알 수 있다.

이상에서 송광사가 큰 화재를 만나 거의 폐사 상태까지 내몰렸음에 도 옛 모습을 완전히 회복하지는 못했지만 이전의 모습에 준할 만큼 ㅇ 勢를 회복할 수 있었던 것은 용운선사를 비롯한 승려들의 헌신적 노력 도 있었지만, 무엇보다 원당 겸 봉산으로 국가의 보호를 받는 비보사찰 로 지정되어 있었기 때문일 것이다.

20)『史庫 건물부』「송광사연혁」에는 제5중창의 중심적 인물임이 용운대사임을 밝히고 있다. 그 내용을 정리하면, 원래 제 5 중창은 ⿹丁ㅁ뇨애사와 용운대사가 함께 추진한 것이었지만, 기봉대사가 연로하여 조정과의 연락 등 전반적 업무를 용운대사가 도맡았다고 한다. 


\section{3. 송광사의 봉산지정과 원당운영}

\section{1) 栗木封山과 香炭封山}

송광사는 순조 30년(1830)에 栗木封山 ${ }^{21)}$ 으로 획정되어 奉常寺의 특별 한 보호를 받게 되었으며, 광무 4년(1900)에는 洪陵의 香炭封山으로 획 정되었다. ${ }^{22)}$ 封山은 원래 ‘抄封之山’이란 뜻으로 민간부분에서의 산림 이용을 제한하는 경계선에 封標를 설정함으로써 나타난 이름이다. ${ }^{23)}$ 특히 이러한 봉산은 조선후기 전란과 민간에서의 산림 자원에 대한 수 요증가와 맞물려 국가가 특별한 용도의 목재를 지속적으로 조달하려 는 목적에서 국가기관이 수목을 보호했던 지역이라고 할 수 있다. 봉산 으로 지정된 곳은 조달해야 하는 목재의 종류에 따라 다양하게 나타났 는데, 그 대부분은 배의 건조나 건축 자재와 관련된 소나무를 채취하는 곳이었지만, 일부특수 용도와 관련된 봉산도 지정되었다. 대표적인 것 으로 黃腸封山, 栗木封山, 眞木封山, 香炭封山 등을 들 수 있다. 봉산으 로 지정되면 그 지역에 대한 지역주민의 산림 경영이 엄격히 통제되고, 해당 관청의 주관 아래 벌채되는 수목의 종류와 양도 법적으로 규정되 었다. 특히 봉산의 대부분을 차지하는 소나무를 배양하는 지역들의 경 우, 벌채에 따른 노역과 산림자원의 개발 제한이라는 측면에서 지역민

21) 현재 학계에 알려진 율목봉산에는 『사고』 에 실린 율목봉산의 내용은 소개되어 있지 않다. 이 는 단지 새로운 율목봉산의 사례를 하나 더 추가한다는 의미 정도가 아니라 율목봉산의 운영실 태를 구체적으로 알려주며, 그에 따른 국가의 대민지배, 대사원지배의 정도를 가늠할 수 있다는 점에서도 매우 중시된다. 또 조계산과 가까운 곳에 자리한 연곡사의 봉산이 그토록 중요하였다 면 송광사의 봉산과 어떤 상호관계에 있었는지도 검토해 볼 가치가 있을 것이다.

22)『史庫 산림부』「송광사연혁」(歷代之封山)

23) 이기봉, 「조선후기 封山의 등장 배경과 그 분포」『문화역사지리』제 14 권 제 3 호, 2002,5 쪽. 
들의 생활에 미치는 영향이 컸다. 이와 관련하여 다음의 자료는 봉산 지정이 일반 지역민의 삶에 미치는 영향을 짐작할 수 있다.

승지 李存秀가 아뢰기를, "신이 영남의 감사로 있을 때, 경주의 封山을 백성들 로 하여금 개간하여 경작하게 하는 일에 대해 사리를 따져 보고하라는 뜻을 묘당 에서 통고한 바가 있었습니다. 그리고 백성들이 비국에 진정서를 올려 봉산을 혁 파할 것을 청하였습니다. 이른바 혁파할 것을 청한 것은 수목이 무성하여 虎患이 많기 때문이며, 水營에서 摘奸할 때 하리들이 誅求하기 때문입니다. 그러나 수백 년 금지하여 기른 80리의 봉산을 괜히 혁파할 수는 없습니다. ${ }^{24}$

위의 기록을 통해서 알 수 있듯이 봉산으로 지정될 경우 지역민들의 경우 토지이용에 있어 제한을 받고, 또한 특정 목재의 벌채와 운반에 있어 지방과 중앙의 담당 관리들로부터 이러저러한 명목으로 수탈당 하고 있었다. 뿐만 아니라 주요 목재와 산림에서 나는 종자 - 송이 · 갈 포재료 - 야생동물에 이르기까지 다양한 산림자원을 채취 공급하여야 했다. ${ }^{25}$ 때문에 지역민들은 해당 지역의 봉산을 혁파하기를 원하였던 것이다. 이처럼 봉산지정으로 국가의 일방적 수취체제 속에 편입됨으 로써 지역민의 경제가 위축되는 경우도 있었겠지만 모든 봉산지정이 동일했다고 보기는 어렵다.

사찰과 관련된 봉산의 경우는 오히려 사찰 측에서 봉산의 지정을 적 극적으로 경우가 대부분인데, 이는 조선시대 사찰경제가 지닌 성격과 관련된 것이라고 생각된다. 사찰로서는 지역향반 또는 지방과 중앙정

24)『순조실록』 순조 16년(1816) 12월 29일조.

25) 권순구, 「조선후기(朝鮮後期) 봉산정책(封山政策)의 분석」『한국정책과학회보』11-1, 2007, 92쪽참조. 
부의 수탈을 벗어날 수 있는 길로서 특정 관원 또는 행정부서와 밀접한 연계를 맺고자 했다. 이는 한편으로 사찰소유의 토지에 대한 지방민의 자의적 이용을 통제할 수 있는 하나의 방법이 되기도 했을 것이다. 또 하나는 특수목을 배양하는 봉산의 경우에는 국가의 적극적인 지원 아 래 오히려각종 역역의 감면 등의 경제적 혜택을 입고 있었던 것으로 보 인다. 송광사 역시 율목봉산으로 지정됨으로써 국가로부터 각종 역역 과 조세 감면의 혜택을 기할 수 있게 됨으로써 조선후기에도 조선전 · 중기에 못지않은 사세를 유지할 수 있게 되었다.

율목봉산은 禮曹의 奉常寺가 주관하였고, 밤나무를 채취할 때에는 敬差官, 泛鐵官을 파견하여 처리하였으며, 神主를 만드는 밤나무 ${ }^{20}$ 재 의 채취는 경상도에서는 매 ⿹⼯요마다 즉 子, 卯, 午, 西가 드는 해에 채 취하였으며, 충청도와 전라도에서는 이 식년 사이사이에 채취토록 하 였다. 율목봉산은 신주를 만드는 목재를 산출하는 곳이기 때문에 主材 封山이라고도 하였는데, 『영조실록』의 영조 21년(1745) 11월 21일 기사에 의하면 이전에는 나라에서 필요로 하는 신주용 목재를 三南의 邑에서 올리는 供物로 충당하였는데, 이때부터 비로소 봉산으로 지정 제도화하여 국가에서 관장하였다고고 한다. 이때 지정된 봉산은 구례 현의 燕谷寺였다. 율목봉산은 전라도 구례와 경상도 하동의 지리산 남 쪽에서만 발견되고 있는데, 이는 율목의 필요량이 船材는 말할 것도 없 고, 황장목보다도 훨씬 적었기 때문에 더 이상의 봉산 지정이 필요하지 않았던 사정과 관련된다.

26) 밤나무를 신주로 사용한 것은 이미 세종실록의 오례의에도 규정되어 있다. 즉『세종실록』 「오례의」 흥례 의식 題位版儀條에 “位版은 밤나무로 만드는데, 길이가 1 尺 2 寸, 두께가 8 分, 너비 가 4 寸이고, $\cdots$ ”라고 나와 있다.

27) 『영조실록』 영조 21년(1745) 11월 21일조 
송광사는 율목봉산으로 지정되면서 봉상시에서 道光 10 년(순조 30 , 1830) 3 월에 작성된 節目을 받게 된다. 봉상시에 내려준 절목의 구체적 인 항목은 모두 18개 조항으로 되어 있는데, 그 내용은 등초되어 監營, 兵營, 水營,鎮營,順天府 등에도 배부되었다.

이에 따르면 조계산 일대에 율목봉산을 설치하기 이전까지는 구례 현 연곡사의 1 洞만이 봉산으로 지정되어 300 주 만을 채취하였는데, 송 광사 뒷산의 동남쪽에 있는 南庵洞을 비롯한 9 개의 골짜기는 산세가 깊고 율목이 울창하여 봉산에 합당하여 경계를 정하고 봉표를 세워 봉 산으로 정하면 밤나무재의 조달에 큰 지장이 없다 하였다. 특히 이곳에 봉산이 설치된 이유를 설명하면서 밤나무재의 경우 삼남에서 채취한 것은 쓸 만한 것이 없고 연곡 - 쌍계의 밤나무만이 쓸 만하였는데 이미 모두 사용하였고, 새로 심은 것은 아직 다 자라지 않았기에 이곳에 봉 산을 설치한다는 것과 봉산 설치에 따라 봉표 내에 사찰과 민호를 송광 사에 이속시켜 송광사로 하여금 관리 감독케 한다는 내용과, 감영, 병

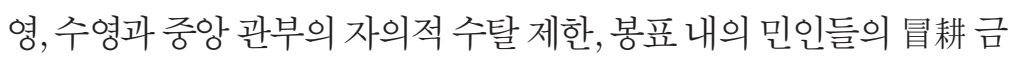
지, 묘소사용 금지 등에 대한 내용이 기록되어 있다.

이 봉산이 지정되는 과정을 보면 조계산을 율목봉산으로 새로이 정 하자는 전라도 관찰사의 장계에 대하여 중앙에서 관리를 파견하여 그 적당함을 살피고서 이에 봉표를 세우고 경계를 정하였다고 되어 있어 마치 국가에서 일방적으로 봉산을 지정한 것처럼 보이나, 사실은 송광 사 측에서 적극적으로 봉산 지정을 위하여 노력하였다. 당시 봉산으 로 지정받기 위해 노력한 이는 慧俊大師였다. ${ }^{28)}$ 이는 봉산 지정을 통해 송광사가 받게 될 각종 경제적 혜택을 염두에 둔 것이라고 생각된다.

28) 산림부에는 封山斡旋主로 慧俊大師임을 밝히고 있다.

발표논문 I 조선후기 송광사 가람중창의 경제적 배경 37 
그런데 산림부에는 1830년에 율목봉산이 지정된 것으로 나와 있으 나, 다음의 기록과는 차이가 있다. 실록의 기록에 따르면 영조 45년 (1769) 8월 3일에 “봉상시에서 전라도의 曹溪山·白雲山29)을 율목봉산 으로 삼기를 계청하니 그대로 따랐다.”고 하여 이미 1769년에 조계산 일대에 율목봉산이 지정된 것으로 나와 있다. 『신증동국여지승람』 에는 전라도의 조계산으로 순천부 이외 興陽과 영암에도 조계산이 있 기 때문에 어느 것을 말하는지는 확실하지 않다. 그러나 율목봉산이 대 체로 지리산 남쪽으로 위치하였다는 기존의 연구를 참조하면 송광사 의 조계산으로 보는 것이 옳을 듯하다. 즉 1745 년 연곡사 일대에 지정 된 봉산만으로는 율목의 충분한 공급이 어려워져서 1769년에는 조계 산 일원으로 부분적인 보충이 있었던 것으로 생각된다. 이후 송광사에 서는 율목봉산의 지정이 가져다 줄 경제적 혜택을 꿈꾸면서 주도적으 로 율목봉산이 되고자 하였고, 그 노력의 결실이 1830 년 이루어진 것으 로 볼 수 있지 않을까 한다.

율목봉산으로 지정됨으로써 송광사는 국가로부터 갖가지 승역 및 조세의 감면을 받게 된다. 율목봉산으로 지정되기 전 송광사는 영조 31년 艈祥宮의 원당이 설립되면서 가장 큰 고역의 하나였던 紙所가 혁 파되었고, 이어서 영조 36 년에는 각 읍에서 송광사의 공장이나 刷還畫 僧을 침탈하는 것을 금지하였으며 ${ }^{30)}$, 영조 42 년에는 각읍의 刻手를 비 롯한 각종의 장인을 쇄환하거나 다른 읍에서의 승려의 쇄환 금지하는

29) 『신증동국여지승람』 제39권 전라도 茂朱縣의 산천조에 “백운산은 무풍 북쪽 15 리에 있다."고 나와 있다. 이곳이 율목봉산으로 지정되었을 가능성은 풍속조에 鄭粼趾의 시를 인용하여 “民 業이 황량하기 해를 거듭하니, 상수리와 밤나무를 저장하여 양식을 삼네."라고 하는 것으로 보아 이곳이 밤나무가 많이 자생하고 있었음을 알 수 있다.

30)『사고 雜部』「禁雜役完文」 
완문이 발급되었다. ${ }^{31}$ 순조 28 년에도 순천부의 향교나 서원의 春秋祭

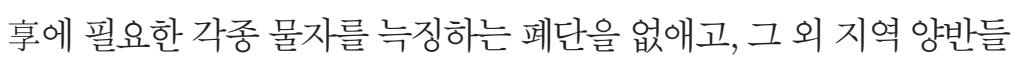
의 变事에 필요한 물자의 징발을 모두 혁파하였다. ${ }^{32)}$ 이러한 감면조치 에도 불구하고 송광사가 짊어져야 했던 역의 부담은 여전히 막대한 것 이었다. 이는 송광사가 순조 30년(1830) 율목봉산으로 지정될 당시 축 常寺로부터 발급받은「栗木封山時寺役存減節目」과 다음 해 암행어 사가 내린「雜役矯革節目」을 통해서 확인된다. 여기에 따르면 송광 사는 순천부 소속 관아 수용의 상당부분을 담당하였을 뿐만 아니라, 감 영, 병영, 수영, 鎮營 등에 대해서도 승역을 비롯하여 각종 부담을 짊어 지고 있었다.

송광사가 부담한 잡역의 종류는 크게 현금징수, 현물징수, 노동력징 수로 구분해 볼 수 있는데 ${ }^{33}$, 현금징수로는 각 色吏들에게 바치는 例納 錢, 현물 상납시의 情錢, 각종 物色의 代錢 및 僧番錢 등과 같은 것이 있었다. 노동력징수로는 塗袹僧, 木手僧, 刻手僧, 畫工僧, 蓋瓦匠, 燔瓦 匠, 印出僧, 勅食僧, 供饋僧, 香盤僧, 藍興軍 등, 전문기술을 가진 승도 와 육체적 노동을 징발하였다. 이러한 노동력 징수 중 가장 큰 부분은 성곽이나 각종 관청의 건물들을 조영하는데에 동원되는 승역이었다. 이러한 승역의 일부는 防錢의 형태로 화폐로 대납되기도 하였는데, 원 당과 봉산이 되었음에도 여전히 그 부담은 큰 부분으로 남겨져 있었다.

31)『사고 雜部』「禁雜役完文」

32)『사고 雜部』「諸般節目撮錄」

33) 송광사의 잡역과 관련해서는 박병선, 「朝鮮後期 願堂研究」, 2002, 영남대박사학위논문, 76 83 쪽을 참조하여 정리하였다. 일부 물품의 이름에 대해서는 박병선과 다른 필자와 견해를 반영하 였다. 예를 들면 長尺을 박병선은 '긴 자라고 소개하였지만 필자는 옷감의 일종으로 이해하였다. 그 외, 眞末, 주홍, 삼록과 같은 물품도 마찬가지이다. 
송광사의 사원경제와 관련하여 주목되는 것은 각종 현물징수이다. 그 품목을 정리하면 다음과 같다.

- 음식류: 白米, 燻造(메주), 曲子(누룩), 愐末(밀가루, 깨소금?), 法油(들기름), 清醬 (간장), 土醬(된장), 醬太(콩), 熊舌

- 약재류 : 松花, 檜花, 익모초, 藥艾(약숙)

- 옷감류: 松板, 각종木物, 杉丁, 衣資, 長尺(?), 熟麻(삼은 삼), 山麻骨(겁질 벗긴 삼)

- 수공업产류: 草鞋白草鞋, 麻鞋, 節扇, 油紙, 繩細繩, 中繩, 大繩, 皮繩, 箭竹( 화살대)

- 기타 : 馬草, 朱紅片·三綠片(안료의 일종), 鼓桶

이상과 같은 다양한 물품들은 송광사 소유의 전답이나 산림에서 생 산, 채집하여 각급 관아에 납품하였다고 할 것이다. 이는 송광사의 사 원경제가 토지뿐만 아니라 다양한 영역에 걸쳐 구축되고 있었음을 말 해 준다. 이와 관련하여 주목되는 것은 송광사에 있던 각종 명목의 창 고들이다. 헌종 8 년(1842) 3 월 2 일의 대화재로 대웅전을 비롯하여 佛宇 5 所, 僧寮 8 屋, 公舍 12 처 등 사찰 서반부의 건물 2,152 간이 불타버렸는 데, 이때 소실된 건물 중에는 다수의 창고가 포함되어 있음이 주목된 다. 그 내용을 살피면 姼役庫 9간, 細大繩庫 12간, 持事庫 9간, 佛糧庫 15 간, 東邊庫 7간, 西邊庫 8간, 客糧庫 5간, 鍮器庫 9간, 甲戌庫 9간, 南 草庫 7간, 油庫 4 간, 䢐沫庫 8 간이다. ${ }^{3 \oplus}$ 이들 각종 명목의 창고들 중 眞 末庫, 油庫, 細大繩庫, 南草庫 등은 송광사가 각 관청에 바치던 현물들

34) 이 화재의 전체적 피해규모의 내역에 대해서는 徐致祥·金純一,「松廣寺 第五重創工事에 관한 研究」『大韓建築學會論文集』6-1(통권27), 1990, 80쪽의 표1. 壬寅火災時燒失建物 참조. 
을 보관하던 창고가 아니었을까 한다. 이는 송광사가 곡식류 이외 다 양한 명칭의 창고를 필요로 할 만큼 사원경제가 종합적이고 컸기 때문 이었을 것이다. 한편 절목에는 송광사와 관련하여 각수나 화공, 인출, 목수, 도배, 와장, 번와장 등의 다양한 이름을 가진 승려들이 존재하고 있는 것으로 보아 가람의 운영과 관련된 각종의 전문장인들이 존재하 고 있었으며, 이들 전문장인들은 사찰 내의 필요물품을 제작하여 공급 하였을 뿐만 아니라, 기와와 같은 경우에는 지역사회에도 판매했을 가 능성이 높다고 생각된다.

1900년 송광사는 기존의 율목봉산 이외에 명성왕후를 위한 줍炭封 山으로 지정되었다. 향탄봉산으로 지정되는 데에도 율목봉산 지정 때 와 마찬가지로 송광사 승려들의 적극적인 대정부교섭이 있었다. ${ }^{35)}$

香炭山은 陵의 제사에 쓰이는 香木과 木炭을 배양하기 위하여 왕릉 부근의 산을 향탄산으로 정하고 나무를 하거나 짐승을 기르는 것을 금 한 곳이었다. 향탄산에 대하여는 대구 팔공산의“綏陵香炭禁界”표석이 보고되어 있고, 향탄산의 이칭이라고 생각되는 炭山, 杳炭山, 炭封山 등이 해동지도 등에 기재되어 있을 정도이다. 『사고』 이외의 문헌자 료에는 송광사가 향탄봉산으로 지정되었다는 기록은 찾을 수 없다. 그 러나 『사고』에는 그 문헌상으로 확인되는 향탄봉산 지정에 따른 절 목이 필사되어 있어 봉산이 담당해야할 의무나 다른 관청에서의 공물 부담 제한 등의 실례를 확인할 수 있다.

향탄봉산 절목에는 光武 4년(1900) 송광사에 향탄봉산을 지정하게

35)『史庫 산림부』「香炭封山」에 의하면 당시 송광사의 栗庵堂과 翠庵堂이 京城委員으로 정부와 교섭하고 있었고, 당시 송광사의 총섭은 錦溟 寶鼎이었다. 송광사가 향탄봉산으로 지정되는 데 에는 이들 3 명의 승려의 노력이 컸다고 할 것이다. 『串庫 건물부』「송광사연혁」에서는 “본사 의 錦溟, 栗庵, 翠庵 세 승려의 주선으로 勅旨를 받았다"고 되어 있다. 
되는 이유와 그 내역 및 그에 따른 免役 등의 상황이 자세히 수록되어 있다. 송광사가 향탄봉산으로 지정되게 된 것은 다음과 같은 사정이 있 었다. 1899년 황실에서는 고려대장경 4부를 인쇄하여 그 중 1부를 송 광사에 봉안하였는데, 이를 계기로 송광사에서는 이전의 원당과 율목 봉산으로서의 위상을 주지시키면서 당시의 어려운 사정을 아뢰게 된 다. 개항기 이후 국법이 해이해지면서 봉산지역에 민간인들의 경작이 나 벌채와 같은 침범이 있었고, 송광사 역시 동일한 피해를 받고 있었 다. 이에 송광사의 건의를 받아들여 洪陵의 향탄봉산으로 지정됨으로 써 다시금 송광사의 궁․ 有林에 대한 지배권을 재확인하게 된다. 이를 통 해 대한제국기의 민간인과 사원간의 산림 이용에 대한 갈등3과과 그 해 결의 방향 등을 이해할 수 있다. 결국 송광사가 향탄봉산으로 지정받 고자 하였던 가장 큰 목적은 송광사의 사유권을 국가로부터 공인받고 자 하는 데 있었던 것으로 생각된다. 봉산으로 지정됨으로써 부수적으 로 순천부를 비롯한 순천부의 각종 관청에 납부해야 할 각종 잡역도 면 제를 받고 있는데, 율목봉산 때와 비교하면 그 양은 그다지 많지 못하 다고 생각된다. ${ }^{37)}$ 그 이유는 이미 율목봉산으로 지정됨으로써 상당 정 도의 승역이 감면되었다는 점과, 개항기 국내외의 혼란 속에 송광사의

36)『史庫 산림부』「분쟁」 에는 율목봉산에 대한 지역민의 침탈과 관련하여 몇 건의 사례가 나와 있다. 1861년에는 接峙 지역의 駕洞과 ㅂ洞의 店民들이 숫을 생산하기 위해 나무들을 벌채하는 데 대해 송광사에서는 등장을 올려 그 금지를 요청하였다. 이는 접치점의 주민들이 시탄을 통해 생계를 꾸려가고 있었기 때문에 소유권 분쟁이라기보다는 산림이용을 둘러싼 분쟁이었다고 생 각된다. 봉산에 대한 지역민들의 침탈은 개항기 이후 더욱 극심해졌다고 보인다. 그것은 1893 년, 1899년, 1900 년 연이어 주암면 · 송광면의 주민들과 송광사간에 분쟁이 계속되고 있었음을 통해 서 확인된다. 이들 지역민과의 분쟁은 봉산이 해제된 이후 더욱 격심해져서 임야권을 둘러싼 지 역민과의 분쟁은 1929 년까지 계속되었다.

37)『串庫 건물부』「송광사연혁」에 의하면 40 조의 금폐절목을 얻어 장례원, 전라도 관찰부, 순천 군에도 동일한 절목이 등초되어 배부되었다. 
사세도 상당히 기울어져 있었기 때문이 아닐까 한다. 사찰의 어려운 사정을 극복하는 하나의 방책이 향탄봉산으로의 지정이었을 것이다.

한편 향탄봉산 절목의 작성에는 洪陵, 景孝殿, 궁내부, 내부, 장예원 의 관료들의 이름이 열기되어 있어 이들 관부가 향탄봉산에 실질적인 관리와 책임을 맡았던 관부로 볼 수 있고, 그들 관부는 각자가 절목을 보유하여 증빙자료로 쓰고 있었다. 이러한 자료를 통해 궁내부가 중 심적인 관부라는 사실 등 향탄봉산 운용의 구체적인 내용을 파악할 수있다.

율목봉산과 향탄봉산은 융희 2 년(1908)에 봉산지정이 해제됨으로써 송광사의 국가에 대한 특수목 관리 및 조달의 임무도 중지되었다. 이 는 통감부체제 아래 조선시대 국가의 봉산정책이 형해화되어 제 기능 을 발휘하지 못하고 있었던 것과 관련이 있다고 생각한다.

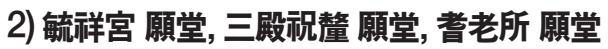

조선후기 사원의 잡역은 종류가 다양하고, 봉납해야 할 관청이 많았을 뿐만 아니라, 상납 물종이나 役事 또한 헐가 내지 무상으로 강제 징발 되는 일이 많았다. 여기에 지방의 사족을 비롯한 토호들에 의한 사원 토색은 사원의 경영을 더욱 궁핍하게 만들었다. 이에 대해 사원은 왕 실원당이 됨으로써 각종 침탈로부터 벗어나고자 했다. 다음의 기사에 서 보듯이 원당이 설립되지 않은 사원에서조차도 원당을 사칭하여 면 역의 혜택을 누리고자 하는 경우도 나타났다.

각 도의 願堂에 대한 폐단을 금지하였다. 대사간 洪檍이 아뢰기를, "각도의 사 찰 중에 원당이라고 불리는 것들은 어느 때에 창시했는지 알 수 없습니다마는, 근 
래에는 더욱 점점 퍼져 거의 온 나라 안에 펼쳐 있습니다. 이는 비록 僧徒들이 官 役으로 쌓인 곤궁 때문에 핑계 대며 보존해 가려는 생각에서 나온 것이기는 하나, 사사로이 位版을 봉안하고 멋대로 享祀하기까지 하니, 䃞瀆스러움이 이보다 심 할 수 없습니다. 일체를 아울러 금단하고, 욤⿱⽕ㅁㄱㅘ 각 고을에서 승도들을 침어하 는 폐단도 또한 준엄하게 신칙하소서." 하였다.( 『정조실록』 1, 즉위년 6월 14 일 계축.)

과중한 승역의 부담은 대찰마저도 그 운영을 어렵게 할 정도였다. 한 때 1,000 명의 승려가 거주할 정도의 곡르를 자랑하던 송광사 역시 원당 설립 이전에는 "바람 부는 가지의 새알이며, 불타는 솥에 노니는 고기 와 같다."고 할 정도로 사원의 규모를 유지하기 어려웠다. 송광사는 영 조 32년(1756)에 영조의 생모인 淑嬪 崔氏의 명복을 축원하는 艈祥宮 원당으로 지정되었는데, 육상궁 원당의 지정을 통해 송광사는 "각 모 吏民들의 㢢瘼이 두절되어 절의 승려들이 안도하여 보존할 수 있는 것 은 원당을 봉안한 덕이며, 조정의 진휼하는 은택이 千里의 佛道에 미치 었다." ${ }^{38)}$ 고 할 정도로 상당한 정도의 경제적 혜택을 받았다.

송광사에 영조 31 년 육상궁의 원당 설립이 결정되자 예조에서 전라 도와 순천부에 관문을 내리고, 관문에 의거하여 道臣과 郡吏는 터를 잡 아 이듬해 송광사에 건물을 신축39)하고 각 읍 吏民의 慜瘼을 막고 寺 僧을 안도케 하였다. 육상궁 원당 설립을 통해 송광사가 누릴 수 있었 던 최대의 경제적 혜택은 紙役의 부과가 크게 줄어든 것이었다. 순천 부에서는 송광사의 紙所 혁파와 더불어 제반 잡역을 침탈하지 못하도

38)『史庫 건물부』「毓祥宮願堂始終記」

39) 육상궁은 別廟의 三門형태를 취하고 있다. 
록 하였다. 순조 28 년에는 순천부의 향교와 서원에 상납하는 油紙·白 紙·皮紙 마저도 혁파되었다. ${ }^{40)} 17$ 세기 이후 닥나무 주산지인 전라도 를 중심으로 주로 삼남 지방의 사원에 지소 설치와 더불어 공납의 역 을 부과하였다. 사세가 크고, 거주승려가 많은 대사원에서는 직접 지 소를 설치하여 종이를 생산하여 공납하거나 본사의 소용에 충당하였 다. 사원의 지역 부담은 심각한 경우에는 사원의 쇠퇴를 불러올 정도 로 심각한 것이었다. 송광사의 경우 지소의 혁파는 사원경제에 상당한 정도 도움이 되었다. ${ }^{41)}$

그에 반해 승역과 더불어 가장 큰 고역 중 하나였던 義僧役의 경우 원당 설립에도 불구하고 큰 혜택을 보았다고 보기 어렵다. 순천부는 영 조 32년 義僧防番錢節目과 명단이 만들어지면서 전국에서 가장 많은 액수가 배정되었는데, 매년 남한산성에 의승 19 명 정액에 1 명당 22 냥 을 부담한 414낭을 상납해야 했다. 그런데 영조대 순천부 관내 사원은 송광사를 비롯해서 6개 사원이 있어 평균 사원당 69낭을 상납해야 했 다. 송광사는 순조 30 년에 僧番錢 58냥 1전 5푼을 상납하고 있는데, 이 때는 율목봉산이 되어서 방번전이 반감된 후였기 때문에 반감되기 이 전에는 116냥 3전을 상납사하였ㅆ다고 볼 수 있다. 송광사가 육상궁 원당 이 되었음에도 이렇게 많은 防番錢을 부담하였던 것은 상주승도 많고 경제력이 풍부하였기 때문이었다.

송광사는 육상궁 원당이 됨으로써 이후에도 지속적으로 국가의 관 심을 받아 영조 36년에는 「禁雜役完文」, 영조 38년에는 「禁奪穀

40) 박병선,「朝鮮後期願堂研究」, 2002, 영남대박사학위논문, 86쪽.

41) 박병선은 육상궁 원당의 설립을 계기로 송광사의 사세가 급속히 성장하였다고 한다. (박병선, 위 의 논문, 71 쪽.)

42) 박병선, 위의 논문, 97 쪽. 
物完文」, 영조 42년에는「禁雜役完文」을 내려 받음으로써 紙所革 罷와 더불어 各邑工匠刷還 및 畫僧刷還을 혁파하거나, 下吏輩들이 진 휼을 빙자해서 사찰의 곡물을 약탈하는 것을 금지하는 등의 減役을 받 게 되었다.

육상궁 원당은 헌종 8년(1842) 대화재 후에 昌平 龍興寺로 이설되 었다. ${ }^{43)}$ 왕실의 원당사원에서 해제됨으로써 송광사는 각급 관청과 향 교 - 서원 등에 다시 紙役을 부담해야 했을 것이다. 이에 송광사에서는 왕실의 원당을 다시 유치하기 위해 지속적으로 노력했다. ${ }^{4}{ }^{4}$ 육상궁 원 당으로 다시 지정받지는 못했지만 그 노력은 고종 23년(1866) 고종 · 민비 · 왕세자 三殿의 축수를 기원하는 祝聖殿을 세우는 것45)으로 일 단 결실을 맺게 된다. 축성전은 처음에는 東方丈에 삼전의 위패를 봉 안함으로써 따로 공간을 갖지 못하였으나 1867년 2,000여 냥의 경비를 들여 새로이 건물을 완공함으로써 독립적 공간을 확보하였다. 또 국 가로부터 1,000 냥을 획급 받아 논 32 斗落을 사들여서 축성을 위한 경비 의 재원으로 삼았다. 이후 고종 33년(1876) 전라도관찰사 尹雄烈은 萬 歲初를 설립하고 스스로 700낭을 시납하였으며, 지방관들에게도 권화 하여 그 이식으로 축성전 보수의 자금으로 삼게 했다. 이상과 같이 축 성전은 건물의 설립과 유지에는 국가로부터 일정한 도움을 받았지만, 국가로부터 원당 설립에 따른 별다른 혜택을 받지는 못했던 것 같다. 그러한 이유로 해서 송광사에는 이후에도 왕실의 원당이 되기 위한 지

\footnotetext{
43)『曹溪山 松廣寺誌』에서는 순조 3 년(1803)이라고 하였으나, 박병선은 용흥사는 이미 영조 21년 에 육상궁 원당이 되어 면세위전답이 하사되고 있었다고 한다. (박병선, 위의 논문, 86쪽 참조.)

44)『曹溪山 松廣寺誌』에 의하면 송광사의 別謄錄에 고종 4 년 11 월에 송광사의 定上房이 원당의 일 로 서울을 왕래하였다고 하여 이때까지 원당 복원운동이 있었다고 하였다.
}

45) 『史庫 건물부』「三殿下祝聖殿記」 
속적 노력을 기울였고, 그 결과 老老所 願堂으로 지정되기에 이르렀다.

송광사는 광무 6년(1902)에 기로소 원당이 되어 고종의 위패를 봉안 하게 됨으로써 국가와 보다 긴밀한 관계를 맺게 되었다. ${ }^{40)}$ 송광사 기로 소 원당은 왕실과 국가의 재정지원으로 경영된 조선조 왕실원당의 마 지막 사례로서, 광무 6년(1902) 고종이 51세가 되자 기로소가 주관이 되어 국왕의 殿牌를 봉안하는 聖壽殿과 前門인 만세문을 송광사에 조 성함으로써 이루어졌다. ${ }^{47)}$ 기로소 원당의 경우 전국의 많은 사찰에서 그 지정을 청원하였는데, 기로소의 次知 李炳鼎은 그의 밑에서 오래 종사하던 前營將 鄭明源의 노고에 보답하는 뜻에서 원당 건립의 監董 職을 差授키로 하고, 송광사를 선정하여 ${ }^{48)}$ 국왕의 재가를 얻은 다음 송 광사로 원당건립의 뜻을 전달하였다.

원당건립의 공사 진행과정은 다음과 같다. ${ }^{49)}$ 광무 6년 10 월 중에는 기로소로부터 공식적인 奉建文書가 송광사로 하달되고, 이듬해 5월에 는 왕실로부터 공사비로 내탕금 1 만량이 하사되었다. ${ }^{50)}$ 정명원을 감동

46)『史庫 건물부』「老老所先生案序」와「송광사연혁」에 의하면 광무 7년(1903)에 비로소 원당 이 설립되었다고 한다.

47) 徐致祥・金純一, 「松廣寺 者老所願堂의 造營에 관한 硎究」『大韓建築學會論文集』5-6(통권 26), 1989.

48) 송광사가 기로소원당으로 지정된 데에는 송광사의 노력도 있었다. 금명보정은 궁궐에 들어와 3 차례나 글을 올렸는데, '백방으로 고생한 모습을 일일이 거론할 수 없다.'할 정도였다. 이를 통해 비록 정명원이 중간에서 매개하기는 하였지만 송광사의 적극적인 대응이 있었음을 알 수 있다.

( 『串庫 건물부』「聖壽殿創建記」)

49) 공사의 진행과정에 대해서는 徐致祥·金純一, 위의 논문, 1989 참조.

50) 기로소원당은 왕실의 절대적 관심 아래 조영되었다. 전체 공사비 22,737 량 10 전 중 내탕전은 거 의 절반을 차지하고 있을 뿐만 아니라, 내탕전을 순천군에서 징수할 結錢으로 바꿔 쓰도록 하였 는데, 결전 징수가 지연되자 고종은 “새로이 건물을 짓는 공사는 마음을 쓰지 않을 수 없으니 마 땅히 각 部에게 甘結하여 기일에 맞게 공사를 끝낼 것”이라 명령이 내려지고, 기로소부터는 結 錢速納과 內帑換用事를 돕도록 탁지부 대신에게 甘結이 내려졌다.(徐致祥·金純一, 위의 논문, 1989, 92梺.) 
으로 한 監董所가 설치되고, 공사를 위한 制下甘結과 各府訓令이 소州 營門과 순천군을 거쳐 송광사로 하달되어 공사가 시작되었다. 광무 7 년 6월 9일에 始役하여 11월 15 일에 건축공사를 완료하고, 12 월 20일 에는 단청공사까지 마무리하여 공사를 마쳤다. 이후 광무 8년 9월 9일 에 奉安视齊를 거행하고 성수전을 額號로 한 本殿에 고종의 殿牌를 봉 안하게 되었다. 이때 기로소로부터 내려진 原堂細則에 따라 院長을 비 롯한 8 인의 寺僧들로 하여금 관리토록 하며, 매 朔望으로 儀禮를 행하 고, 전각 내외에 퇴락이 생기면 즉시 修補토록 하는 등의 관리지침이 하달되었다.

기로소 원당은 공사 과정에서 경비 및 자재의 운반에 이르기까지 각 급 관청이 직간접적으로 관여하고 있었을 뿐만 아니라 고급 기술의 목 수들이 동원됨으로써 국가의 관심이 매우 컸다. 그 한 예로 성수전은 조선후기 사찰건축에서 흔히 사용되지 않던 熟石加工된 礎石이나 정 연한 架構部材의 治木, 엄정한 간살치수 등은 왕실원당에 대한 존엄성 의 표현으로 이를 위한 철저한 공사관리가 있었음을 짐작할 수 있다.

이와 같이 국가의 지대한 관심 아래 기로소 원당이 설치됨으로써 송 광사는 일정한 정도 경제적 혜택을 받았을 것으로 생각되지만 관련 절 목이 남아 있지 않아 자세한 사정은 이해할 수 없다. 원당세칙에 보이 는 것처럼 設齋나 건물 보수만을 위한 경비가 책정되지는 않았을 것이 다. 설령 원당 설립에 따른 경제적 혜택이 없었다고 해도, 지방관의 배 려 아래 삼전축리 원당이 유지된 이상으로 송광사의 사격이 높아지고, 나아가 각종 수탈로부터도 좀 더 벗어날 수 있게 되었을 것이다. 기로 소 원당은 융희 2년(1908) 율목 - 향탄봉산이 폐지될 때 함께 폐지되었 다. 


\section{4. 맺음말}

오늘날 전통사찰들이 일정한 정도의 규모를 유지할 수 있었던 것은 조 선시대 불교탄압의 현실을 슬기롭게 극복한 사원의 자구적 노력에 의 한 것이었다. 본고는 사원의 자구적 노력을 통한 가람의 규모를 유지할 수 있었던 구체적 실례를 조선후기 松廣寺의 중창을 통해 살펴보았다.

먼저 조선시대 송광사는 약 3,000간에 달하는 건물과 3 400명에 달 하는 승려들이 거처하는 대찰이었다. 특히 일시적이나마 영조 연간에 는 1,000 여 명이 머물 정도로 대찰로서의 가람의 규모를 유지하고 있었 다. 이러한 사세를 유지하기 위해서는 송광사가 소유한 토지경영이나, 각종 維持寶를 통한 수입의 마련은 절대적이었다.

임진왜란 이후 제 4 중창을 거쳐 대가람의 면모를 유지하던 송광사는 헌종 8년(1842) 3월의 대화재로 대웅전을 비롯한 2,152간에 달하는 건 물들이 소실됨으로써 전체 규모의 $2 / 3$ 이상의 건물이 소실되는 큰 피 해를 입었다. 이에 따라 제5중창이 시작되었는데, 제 5 중창은 국가의 적 극적 지원 아래 13 년에 걸친 대역사 끝에 이루어졌다. 국가지원의 명분 은 송광사가 艈祥宮 願堂이자 栗木封山이었기 때문이다. 즉 송광사는 화재로 인해 거의 폐사 상태까지 내몰렸다가 다시 이전의 모습에 비견 될 만큼 사세를 회복할 수 있었던 것은 송광사 승려들의 헌신적 노력도 있었지만, 무엇보다 원당 겸 봉산으로 국가의 보호를 받는 비보사찰로 지정되어 있었기 때문이다.

송광사는 순조 30년(1830)에 栗木封山으로, 광무 4년(1900)에는 洪 陵의 즙炭封山으로 획정되어 국가가 필요로 하는 산림자원을 제공하 였다. 조선후기 국가의 산림정책에 따라 봉산으로 지정되면 지역민들 의 토지이용이나 벌채시 지방의 담당 관리들로부터 이러저러한 명목 
으로 수탈당하는 경우가 많았기 때문에 지역민들은 봉산지정을 꺼리 는 것이 대부분이었다. 그러나 특수목을 배양하는 봉산의 경우에는 국 가의 적극적인 지원 아래 오히려 각종 역역의 감면 등의 경제적 혜택을 입고 있었다. 때문에 사찰로서는 봉산으로 지정되기를 원하기도 하였 다. 송광사 역시 율목봉산과 향탄봉산으로 지정됨으로써 국가로부터 상당한 정도의 조세와 승역의 감면을 기할 수 있었다.

송광사는 율목봉산으로 지정되면서 봉상시에서 작성된 節目을 받았 는데, 절목은 등초되어 監營, 兵營, 水營, 鎮營, 順天府 등에도 배부되 었다. 송광사에서는 적극적으로 봉산으로 지정되기 위해 노력하였는 데, 이는 봉산 지정을 통해 송광사가 받게 될 각종 경제적 혜택을 염두 에 두었기 때문이다.

송광사는 봉산으로 지정되기 이전에는 순천부를 비롯한 지방관아 에 다양한 종류의 승역을 부과받고 있었는데, 송광사가 부담한 잡역의 종류는 크게 현금징수, 현물징수, 노동력징수로 구분해 볼 수 있다. 송 광사가 지방관아에 부담한 각종 물품과 승역을 통해 조선후기 송광사 의 사원경제가 종합적이면서도 매우 컸음을 짐작할 수 있는데, 이는 송 광사에 설치된 姼役庫, 細大繩庫, 持事庫등 각종 창고의 존재를 통해 서도 짐작할 수 있다. 한편 송광사는 1900 년에는 홍릉의 향탄봉산으로 지정되었는데, 여기에도 송광사측의 적극적 노력이 있었다. 향탄봉산 으로 지정받고자 했던 주된 이유는 개항기 이후 곡有林을 둘러싼 지역 민과 경제적 분쟁에서 송광사의 사유권을 국가로부터 공인받고자 하 는 것이었다.

이러한 봉산지정과 더불어 송광사의 경제에 큰 도움이 된 것이 원당 의 설립이었다. 송광사는 영조 32년(1756)에 艈袢宮 원당이 설립됨으 로써 국가의 비호를 받아 紙役을 비롯한 다양한 승역을 감면받음으로 
써 대찰로서의 면모를 유지하게 된다. 그러나 헌종 8년(1842) 이후 육 상궁 원당이 昌平 龍興寺로 이전됨으로써 송광사가 받았던 각종 경제 적 혜택도 사라졌다. 이에 송광사에서는 왕실 원당을 다시 유치하기 위해 지속적으로 노력을 경주하였고, 그 결과 고종 23년(1866)에는 고 종·민비 · 왕세자의 축원을 위한 삼전축리 원당이 되고, 1902년에는 고종의 기로소 원당으로 지정되기에 이르렀다. 국가의 지대한 관심 아 래 기로소 원당이 설치됨으로써 조선후기 육상궁 원당시절만큼의 경 제적 혜택은 아니더라도 송광사의 사격의 상승과 더불어 각종 수탈로 부터 벗어났다. 


\section{참고문헌}

- 권순구,「조선후기(朝鮮後期) 봉산정책(封山政策)의 분석」『한국정책과학회보』11-1, 2007.

- 김갑주, 『朝鮮時代寺院經濟㸴究』, 동화출판공사, 1983.

- 김정문 · 정룡 · 김재식, 「曹溪山 松廣寺의 空間 構成原理에 關한 㸴究」『韓國傳統造景學會 誌』23-1, 2005 .

- 박병선, 「朝鮮後期 願堂䃝究」, 영남대박사학위논문, 2002.

- 徐致祥·金純一, 「松廣寺 耆老所願堂의 造營에 관한 㗏究」『大韓建築學會論文集』5-6(통 권 26), 1989.

- 徐致祥·金純一,「松廣寺 第五重創工事에 관한 㸴究」『大韓建築學會論文集』6-1(통권27), 1990.

- 오경후, 「朝鮮後期 佛敉界의 變化相」『慶州史學』22, 2003.

- 윤용출, 「17세기 이후 僧役의 강화와 그 변동」『조선후기의 요역제와 고용노동』, 서울대학 교출판부, 1998.

- 이기봉,「조선후기 封山의 등장 배경과 그 분포」『문화역사지리』14-3, 2002.

- 한상길, 「개화기 사찰의 조직과 운영」『불교근대화의 전개와 성격』, 조계종 불학연구소, 2006.

- 한상길, 「조선후기 사원의 불사와 寺刹契」『佛敉學報』28,2011. 